\title{
The Impact and Countermeasures of RMB Appreciation on Export-Based Enterprises in China
}

\author{
Min Yuan \\ School of Economics, Tianjin Polytechnic University \\ Tianjin 300387, China \\ E-mail: wuna0915.student@sina.com \\ Zhuang Zhou \\ School of Economics, Tianjin Polytechnic University \\ Tianjin 300387, China \\ E-mail: zhouzhuang@tjpu.edu.cn
}

\begin{abstract}
RMB appreciation will pose a challenge to export-based enterprises in China, and bring a sense of crisis to them. Therefore, China's export enterprises should take active measures to deal with the impact caused by the RMB appreciation, so that export-oriented enterprises can better adapt to the changes in the global economy, thus materializing their sustainable and stable development.
\end{abstract}

Keywords: RMB appreciation, Export-based industries, Pros and cons, Countermeasures

The appreciation of the RMB has become much-discussed focus in the international economy and society. China has begun to implement the managed floating exchange rate system based on market supply and demand, with reference to a basket of currencies. RMB exchange rate is no longer pegged only to the U.S. dollar, and instead China has formulated a more flexible RMB exchange rate mechanism. RMB appreciation will pose a challenge to export-based enterprises in China, and bring a sense of crisis to them. Therefore, China's export enterprises should take active measures to deal with the impact caused by the rising Yuan, so that export-oriented enterprises can better adapt to the changes in the global economy, thus materializing their sustainable and stable development.

In June, 2008, the exchange rate of RMB against the U.S. dollar exceeded the 7:1 boundary. The trend of a Yuan's rise is foreseeable, and in the irreversible environment, we must take appropriate steps to prevent large fluctuations in RMB to mitigate its negative impact on the import and export trade, while at the same time making full use of the small rise in yuan to promote trade development. Yuan's rise is not only conducive to a decrease in import costs and domestic inflation, stimulation to consumption, acceleration of structural adjustment, promotion of foreign investment and the reduction in trade friction, but in the short term will also have a negative impact on exports, influencing foreign investment and employment.

\section{Major industries damaged by and benefitting from Yuan's rise}

The impact of a Yuan's rise on various kinds of sectors varies according to the different characteristics of industries. RMB appreciation brings advantages to the industries that need to import raw materials, but is not favorable to ones that are export-oriented. It also brings opportunities to the upgrade and optimization of these industries, though certain industries will be adversely affected by it.

The main industries benefitting from Yuan's rise are as follows: (1) real estate and infrastructure ones, which belong to the non-real estate industry, with its domestic real estate value comprehensively enhanced by a rise in Yuan; (2) ones such infrastructure industries as airports, ports, railways, and highways characterized by limited resources, monopoly, the long construction period, and small supply elasticity; (3) the financial sector, especially banking and securities, which is among capital-intensive industries dealing with currencies and capital. Because of good liquidity, it is categorized into the industry with a high value of RMB assets, benefitting from attracting a large amount of international capital; (4) ones such as aviation, electricity, oil refining, paper-making, engineering machinery, and so on, which will see a reduction in costs owning to its main dependence on procurement of foreign raw materials or 
equipments, or because of the benefits resulted from large amounts of external debt service and the exchange gains and losses, in particular the aviation industry with the dominance of the domestic market; (5) high-tech ones relying upon importing technology, which don't have any advantage in intellectual property rights related to key sciences and technologies, will also maintain the momentum of a large amount of imports in a certain period of time, and are able to keep up their advantage in costs under the premise of a rise in Yuan.

Major industries damaged by Yuan's rise are as follows: (1) as for export-oriented ones, such as the textile industry (especially garment industry with the high degree of dependence on exports more damage, followed by the cotton spinning industry and wool industry), household appliances, building materials, whose product competitiveness will be weakened to a large extent; (2) foreign trade enterprises have a disadvantageous position in the industry chain, and their import business will be unable to gain excess profits from the appreciation of the RMB, with the export business suffering a lot; (3) mining, petrochemical, and non-ferrous metal industries, which will be given a big blow by their export business; (4) agriculture with a larger proportion of exports.

\section{The impact of RMB appreciation on China's export enterprises}

\subsection{Adverse effects on China's export enterprises}

\subsubsection{The export of manufactured goods is greatly affected by fluctuations in exchange rate on a wide basis}

RMB appreciation will induce a increase in currency exchange cost in Chinese export firms, resulting in the loss of price advantage. The cost refers to the RMB cost paid domestically on the net revenue from one dollar' worth of exports. China's manufacturing exports are more concentrated on low-end products, with competitive advantage weak. These products compete with other ones mainly by means of prizing, and as a result the Yuan's rise will have a retarding effect on their exports. For employees in the manufacturing sector, those that are seriously affected may face the reduced income, or even the risk of unemployment. The adverse impact of enterprises in labor-intensive industries will be greater than ones in capital-intensive industries.

\subsubsection{Causing a slow growth in the export of most of products related to raw materials}

The majority of products related to raw materials don't have any competitive edge in the export price, with a stronger reliance on the exchange rate, such as paper, cotton yarn, black metal (steel, manganese, etc.), aluminum, wood and other decorations. RMB appreciation will induce a slow growth in exports of these primary products and raw material products, having a negative impact on economic growth in the short run. It will also reduce the exports of crude oil, refined oil, timber, copper, gold and other resource-based commodities, and bring about the loss of the enterprises, worse still such cascade effects as increased unemployment and banking bad debts. Because our resources are not rich, these resource-based products belong to highly energy-consuming and polluting industries. Over-exports of resource-based products make it easy to intensify the tense contradiction between domestic coal, electricity and oil transportation in the short term. In the long term, it will increase the pressure of the domestic environment and resources, which is not conducive to the sustainable development of the domestic economy.

\subsubsection{The psychological effect of trade impact on people}

In the international market, the increase in production costs will be passed on to the price, and consequently the exchange rate appreciation will not affect the profits of these enterprises too much. China's export products cause the price fluctuations in foreign countries due to our currency appreciation, and the appreciation of the RMB will increase the domestic production costs of these enterprises, and in the international market these enterprises have a substantial cost advantage, with the minimal impact on the interests of traders. However, those with ulterior motives will instigate a negative psychological effect on China in the international community. People will believe the prices of products from China are higher, and foreign businessmen also believe that they will not made a lot of money from products imported from China, which causes the really adverse impact on China's exports.

\subsection{Beneficial effects on China's export enterprises}

\subsubsection{Enhancing the independent innovation capacity of enterprises}

At present, China is at a stage of technology overtaking, and enterprises have a strong capacity of technology introduction, digestion and absorption. And the Yuan's rise can reduce the cost of independent development, indirectly promote the technological upgrading of firms and enhance their core competitiveness, thus speeding up the pace of optimizing and upgrading the industrial structure and boosting the structure adjustment of exports.

\subsubsection{Optimizing the structure of introduced foreign capital}

RMB appreciation makes improve the treatment of workers, which is beneficial to attracting high-tech talents. Under the prerequisite of the country's independent innovation and technological progress, foreign capital will invest in those industries with a high technological content, thereby promoting industrial structure upgrading and optimizing the structure of exports. 


\subsubsection{Promoting China's enterprise investment overseas}

For enterprises to invest directly in foreign nations, they must use the currency of investment destination country. The RMB appreciation significantly reduces their overseas investment costs, and meanwhile enhances the firm's international purchasing power and capacity of foreign investment, paving the way for a part of powerful enterprises to implement "going out" strategy.

\subsubsection{Facilitating the development in service and trade industries}

RMB appreciation can most effectively crowd out those firms in the manufacturing sector with low technology content and added value, poor management and low efficiency, to the benefit of changing the situation of excessive resources gathering to export industries (mainly the secondary industry), and thus make industrial structure service-industry-oriented, promoting the optimization and upgrading of industrial structure and facilitating the rapid development of service industries including trade services. This way, the coordinated development can be ultimately realized between service and commodity trade, enhancing the country's overall competitiveness.

\subsubsection{Boosting China's imports of raw materials and technology}

The prices of foreign consumer goods and capital goods are lower than ever before, and manufacturers dependent on importing raw materials witness a decline in costs, such as steel, electrolytic aluminum, gasoline, oil and other consumption goods more and more dependent on imports. China's industrialization need to purchase a large number of advanced foreign technology; the appreciation of the RMB can reduce the purchase cost of foreign technology. As imports increase, the purchasing power of foreign raw materials increase, with exports declining, so it is helpful to ease the current trade surplus, enhance the balance of China's international balance of payments and weaken the formation of the RMB foreign exchange accounting, and improve the independence and initiative of monetary policy and the balance of money supply.

\subsubsection{Reducing pressure from external debt servicing}

The appreciation of the RMB is advantageous to repaying foreign debts, and there is a corresponding reduction in the amount of outstanding extern al debt servicing.

\subsubsection{Strengthening the international purchasing power of common people in our country}

As the exchange rate rises, the prices of foreign consumer goods purchased by ordinary people will fall, promoting the import of consumer goods. At the same time the drop in the cost of travel abroad can promote the growth of national consumption.

\section{Counter-measures by China's export firms after RMB appreciation}

In theory, the rising RMB exchange rate is bound to have a negative effect on China's export enterprises, but according to the actual trade volume, it' s still uncertain whether the rise in the RMB exchange rate lead to such results, which can be verified by the fact that China's foreign trade volume continues to maintain a favorable balance. However, export enterprises should response in a positive manner under the premise of the growing appreciation of the RMB.

\subsection{Avoiding exchange rate risk is an expedient measure for export enterprises to grapple with the appreciation of the} $R M B$ in the short run

Faced with the steadily rising RMB exchange rate, export enterprises must take precautions, apart from enhancing its anti-risk capacity. In addition, financial instruments developed by banks and other financial institutions must also be relied on to be hedged against risks and prepare more "life buoy", so as to achieve the purposes of avoiding risks and improving operational efficiency.

3.1.1 Focus on the RMB exchange rate changes, and increase exchange rate risk awareness

Concern about the RMB exchange rate changes is one of long-term management tasks in export businesses, with great importance attached to this. Special force must be organized to learn exchange rate management knowledge and closely track the movement of the RMB exchange rate changes, in particular the movements in the recent exchange rate of RMB against the U.S. dollar, euro, Japanese Yen, and other major currencies. Firms have to conduct an in-depth study of the impact of RMB appreciation on export products, and strive to improve the relevance and effectiveness of work. Export enterprises should enhance the risk awareness of exchange rate changes, take control of the effective means of exchange rate risk, and continuously boost their capacity to deal with exchange rate risk. For instance, when signing export contracts, firms can add some relevant provisions of avoiding exchange rate risk to prevent unexpected situations.

3.1.2 Flexibly use various financial tools to lock and avoid exchange rate risks

Flexible and effective financial instruments should be adopted, such as the use of multi-currency clearing method to transfer exchange rate risk, appropriate use of foreign exchange forward trading, hedging and other means to lock the exchange rate risk. Through the appropriate U.S. dollar loans, interest payments and the losses can be reduced. In addition, under the conditional premise, this method can be used to keep the exchange rate risk within the business source through long-term foreign exchange transactions, options transactions and foreign exchange futures trading. 
3.1.3 Accelerate the realization of exports, and reduce the occupation of receivable foreign exchange accounts

Export enterprises accelerate the documentation transfer, strive to withdraw export documentations as soon as possible, actively take notes trade, factoring and other ways to make timely settlement in hand instruments realizable, and use this method to implement the money worth more than half of the export volume into cash. Enterprises should carry out the more rapid recovery of the export business, appropriate control of the export business with a long recovery period, and at the same time increase the collection of receivable foreign exchange accounts, thus shortening the settlement period and reducing in-transit funds occupation as soon as possible.

3.1.4 Increase foreign exchange liabilities, and strike a balance between foreign exchange income and expenditure Through the application of remittances, enterprises can replace Yuan loans for foreign exchange loans, delaying payment of imports and appropriately increasing foreign exchange liabilities. After the appreciation of the RMB, the amount of outstanding loans due to sell or buy foreign exchange return and external payment can be used to offset the risk of devaluation of foreign exchange assets, or directly profit from it.

\subsection{Main strategies for export enterprises to deal with the long-term appreciation of the RMB}

In the evasion of exchange rate risk, the pace of restructuring needs to be accelerated, and the ability of independent innovation and competitiveness enhanced. By strengthening internal management, carrying out technological transformation to develop the potential, and taking the road of branding, this is the long-term and fundamental solution to enterprise development.

\subsubsection{Enterprises carry out the "going out" strategy}

We ought to solve problems related to ideas, accelerate the pace of opening to the outside world, and encourage strong, qualified enterprises to conduct foreign investment and overseas acquisition of the ore, nonferrous metals and other important resources. In particular, electrolytic aluminum enterprises should give full play to the available import-export rights, invest in foreign nations and establish a supply base of stable alumina, bauxite and other resources. In the case of the appreciation of the RMB, the prices of imported raw materials can increase, further reducing production costs. We should seriously study the feasibility of setting up factories in developing countries and regions, develop new products, and increase the technological content of products. The value-added products should be increased, enterprise costs management strengthened, and production and operation costs lowered. The government should choose low value-added processing enterprises with sales network support them to set up production plants and put departments and services at home in these countries with lower labor costs, which can not only use goodwill and marketing networks built up for many year, but also keep part of work positions, thus achieving the curve exports and reducing the trade surplus with major trading countries and the pressure on RMB appreciation.

\subsubsection{Optimize the structure of export commodities, and vigorously develop the international market}

Export enterprises, especially production-oriented enterprises, ought to actively use new technology, develop new products and continuously improve the value-added products, reducing the exports with lowest profits and expanding own-brand product exports of good quality and efficiency. In addition, export enterprises should conscientiously strengthen the costs and cost management of procurement, production, marketing, financial planning and other aspects, fully develop the internal potential, and reduce costs and expenses, expanding product margins and increasing the competitiveness of export products. Only this way is the risk of exchange rate fluctuations avoided. During the RMB revaluation period, adjusting industrial structure of exports is a top priority. The international market is not infinite, and the traditional theory of comparative advantage in the international trade is greatly challenged. Some countries which have industries with comparative advantages face the issue of out-of-step growth in demand for international trade in the international market. This means that the protection of these industries may not be conducive to the long-term development of enterprises.

\subsubsection{Speed up the upgrading of products, and improve the quality of export products}

China is a manufacture-based country. If a product is sold well, there will be many homogenized products available on the market overnight, especially export enterprises. Many of China's enterprises are in the phrase of pursuit of survival, and lack long-term brand planning. The majority of export products win at low prices. Export enterprises based on production should increase technical transformation investment, speed up product upgrading, and strive to improve product quality and added value, improving the comprehensive competitiveness of export products and taking the road of difference and branding. The appreciation of the RMB may force some companies to upgrade products, enhancing export competitiveness in terms of quality and brand. At the moment, many light industrial products, particularly export products with high added value and high-tech content, remain relatively short. Therefore, enterprises should gradually conduct product restructuring and integration of resources, and vigorously develop the international market and export diversification strategy, achieving the output from product to capital and brand, product structure adjustment, and improvement in product quality and grades. Efforts to adjust the structure of export commodities need to intensified, and the opportunity of the appreciation of the RMB caught to actively import advanced equipment and technology, key components, promoting the restructuring in export industries and technological upgrading and transforming the mode of foreign trade growth. 


\section{References}

Phelps, E.S. (1994). Structural Slumps: The Model Equilibrium Theory of Unemployment, Interest, and Assets. Cambridge, Mass: Harvard University Press.

Rotemberg, J.J and M. Woodford. (1991). Mark-Ups and the Business Cycle. NBER Macroeconomics Annual, (6)63-129.

Sachs, J.D and H. J. Shatz. (1994).Trade and Jobs in U.S. Manufacturing. Brookings Papers on Economic Activity, (1): $1-80$. 